Western North American Naturalist 69(2), () 2009, pp. 149-154

\title{
FACTORS INFLUENCING SELECTION OF ROAD CULVERTS AS WINTER ROOST SITES BY WESTERN BURROWING OWLS
}

\author{
Damon Williford ${ }^{1,2}$, Marc C. Woodin ${ }^{3}$, and Mary Kay Skoruppa ${ }^{3}$
}

\begin{abstract}
The conversion of coastal prairie to farmland in southern Texas has drastically reduced the number of available animal burrows, thereby forcing western Burrowing Owls (Athene cunicularia hypugaea) wintering in southern Texas to use nontraditional roost sites such as roadside culverts. We studied factors influencing the selection of road culverts as roost sites by Burrowing Owls by comparing characteristics of 34 occupied and 100 unoccupied culverts. All occupied culverts were in agricultural habitat. Culverts with small diameters $(\leq 16 \mathrm{~cm})$ and those with an east-west orientation were occupied by Burrowing Owls in greater proportions than were culverts with larger diameters or different orientations. Occupied culverts were also associated with absence of grass, absence of woody vegetation, and presence of crop stubble. Our results provide guidelines for making drainage culverts more attractive to Burrowing Owls, but use of roadside culverts by Burrowing Owls may expose the owls to an increased risk of mortality from vehicle collisions. To avoid this dilemma, our guidelines for culverts could also be adapted as criteria for installation of artificial burrows in habitats suitable for wintering Burrowing Owls.
\end{abstract}

Key words: Western Burrowing Owl, Athene cunicularia hypugaea, winter, roost-site selection, road culvert, Texas.

The Western Burrowing Owl (Athene cunicularia hypugaea) is considered a National Bird of Conservation Concern by the United States Fish and Wildlife Service (Klute et al. 2003). Populations of this subspecies have experienced widespread decline, and its range has contracted (James and Ethier 1989, Shyry et al. 2001, Wellicome and Holroyd 2001). Several factors have been suggested as reasons for the decline of the Burrowing Owl, including the loss of nesting habitat to agriculture (Clayton and Schmutz 1999), pesticides (James and Fox 1987), the eradication of burrowing mammals (Butts and Lewis 1982, Desmond et al. 2000, Machicote et al. 2004), and collisions with automobiles (Haug et al. 1993).

Christmas Bird Counts in Texas have indicated a downward trend in wintering Burrowing Owls (McIntyre 2004). The Western Burrowing $\mathrm{Owl}$ has been reported as an uncommon winter resident in southern Texas (Rappole and Blacklock 1985), but this may be related to the habit of Burrowing Owls in winter to be distributed sparsely over extensive agricultural areas. Successful management of a migratory bird species requires a comprehensive understanding of its winter ecology, but this is lacking for Burrowing Owls (Holroyd et al. 2001; but see Woodin et al. 2007). Although a large body of data exists on the use and selection of nest and roost sites by the Burrowing Owl in its breeding range (MacCracken et al. 1985, Rich 1986, Orth and Kennedy 2001, Restani et al. 2001, Smith and Belthoff 2001, Belthoff and King 2002, Poulin et al. 2005), only a few studies in Arizona (Estabrook 1999), Texas (Ortega 2003, Williford et al. 2007, Woodin et al. 2007, Keppers et al. 2008), and Oklahoma (Butts 1973) have focused on use and/or selection of winter habitat and roost sites.

While unusual roost sites for Burrowing Owls have been documented regularly in Texas and elsewhere (Coulombe 1971, Gleason and Johnson 1985, Rich 1986, Trulio 1997, Williford et al. 2007), the use of road culverts has not been reported widely in the literature. Abbott (1930) reported that Burrowing Owls residing within the city limits of San Diego, California, lived in culvert drains beneath the streets. Williford et al. (2007) found that wintering Burrowing Owls in agricultural areas often utilized road culverts made of concrete, steel, or cast iron, which accounted for $74 \%$ of all roost sites. We examined factors influencing selection of roadside culverts by comparing characteristics of culverts used as roost sites

\footnotetext{
${ }^{1}$ Texas A\&M University-Corpus Christi, Department of Life Sciences, Corpus Christi, TX 78412.

${ }^{2}$ Present address: Texas A\&M University-Kingsville, Caesar Kleberg Wildlife Research Institute, Kingsville, TX 78363. E-mail: rook137@gmail.com

Present address: Texas A\&M University-Kingsville, Caesar Kleberg Wildlife Research Institute, Kings
${ }^{3}$ United States Geological Survey, Texas Gulf Coast Field Research Station, Corpus Christi, TX 78412.
} 
with characteristics of culverts not used by Burrowing Owls.

\section{Study Area}

The study area comprised Nueces and San Patricio counties $\left(3989 \mathrm{~km}^{2}\right)$ in southern Texas (Fig. 1). These 2 counties are part of the region known as the Coastal Bend of Texas, which is located on the lower Texas Gulf Coast. The study area is located within the Tamaulipan Biotic Province (Blair 1950), most of which is now included in the Tamaulipan Brushlands Bird Conservation Region (Rich et al. 2004). The Coastal Bend has a subtropical climate and receives an average of $76 \mathrm{~cm}$ of rain per year, but it is often subject to drought. The Coastal Bend consists mostly of flat land characterized by mixed prairies, transitional riparian forest, oak savanna, and Tamaulipan thorn scrub (Rappole and Blacklock 1985); however, much of the native prairie and brushlands in the Coastal Bend have been converted to farmland (Price and Gunter 1943, Smeins et al. 1991). Sorghum and cotton are among the most important crops grown in the area, but corn and hay are also grown. Fire suppression has allowed brush species, such as honey mesquite (Prosopis glandulosa), to invade remaining native grasslands (Johnston 1963).

Most farmland in southern Texas occurs within a network of rural county roads. In addition, temporary roads often are constructed through cultivated fields to service oil and gas wells. Vegetation along rural roadsides is usually dominated by nonindigenous grasses such as Kleberg bluestem (Dichanthium annulatum), buffelgrass (Pennisetum ciliare), and bermudagrass (Cynodon dactylon). To provide drainage during heavy rains, culverts are constructed under these roads. Hereafter, the term "culvert" refers to any pipe of varying size and material used for drainage under a road.

\section{Methods}

Culverts used by Burrowing Owls as roost sites were located by driving on rural roads in agricultural or open pasture areas and checking road culverts. Driving surveys are effective methods of detecting Burrowing Owls when the goal is to maximize the number of owls or nest sites found per hour of survey time (Conway and Simon 2003). Burrowing
Owl roost sites were also located by using public outreach to establish contacts with local farmers and birders. Pellets and/or droppings near or at a culvert, or the sighting of a Burrowing Owl, confirmed the use of a culvert as a roost site. The winter period for this project was designated as 15 November 2001-15 February 2002; any owls discovered before or after this period were considered migrants, and their roost sites were not included in the study.

We recorded the following characteristics of 34 occupied culverts: (1) diameter and (2) directional orientation of openings. Burrow diameter was measured to the nearest centimeter. Each roost site diameter was classified as small $(\leq 16 \mathrm{~cm})$, medium $(17-24 \mathrm{~cm})$, or large $(\geq 25 \mathrm{~cm})$. A compass was used to classify the orientation of culvert openings as east-west, north-south, northeast-southwest, or northwest-southeast. Within a 10 -m radius of 24 occupied roost sites, percentages in increments of $5 \%$ were visually estimated for each of the following types of ground cover composition: (1) bare ground, (2) grass, (3) forbs, (4) crop stubble, (5) litter, and (6) woody vegetation.

The same data were recorded for unoccupied culverts along rural roads in Nueces and San Patricio counties. We selected a total of 100 unoccupied culverts (49 in Nueces County and 51 in San Patricio County) to ensure an adequate sample size (exceeding the numbers of used culverts) of unoccupied culverts from each county. The starting points along rural roads were selected randomly, as was each successive choice of direction (right or left), by flipping a coin at intersections. Data collection for occupied and unoccupied culverts was completed in the late winter period (15 January-15 February) to allow for locating as many used roost sites as possible. After the field season was over, we verified that no roost site classified as unoccupied had been used by a Burrowing Owl. We did this by confirming the absence of feces, pellets, feathers, and scrapes at the site.

Chi-square tests using 2-way contingency tables were used to identify associations between occupancy of culverts (presence or absence of owls) and the following variables: (1) diameter size class and (2) orientation of openings. Percentage data of ground cover at roost sites could not be normalized, so we converted these continuous variables to 


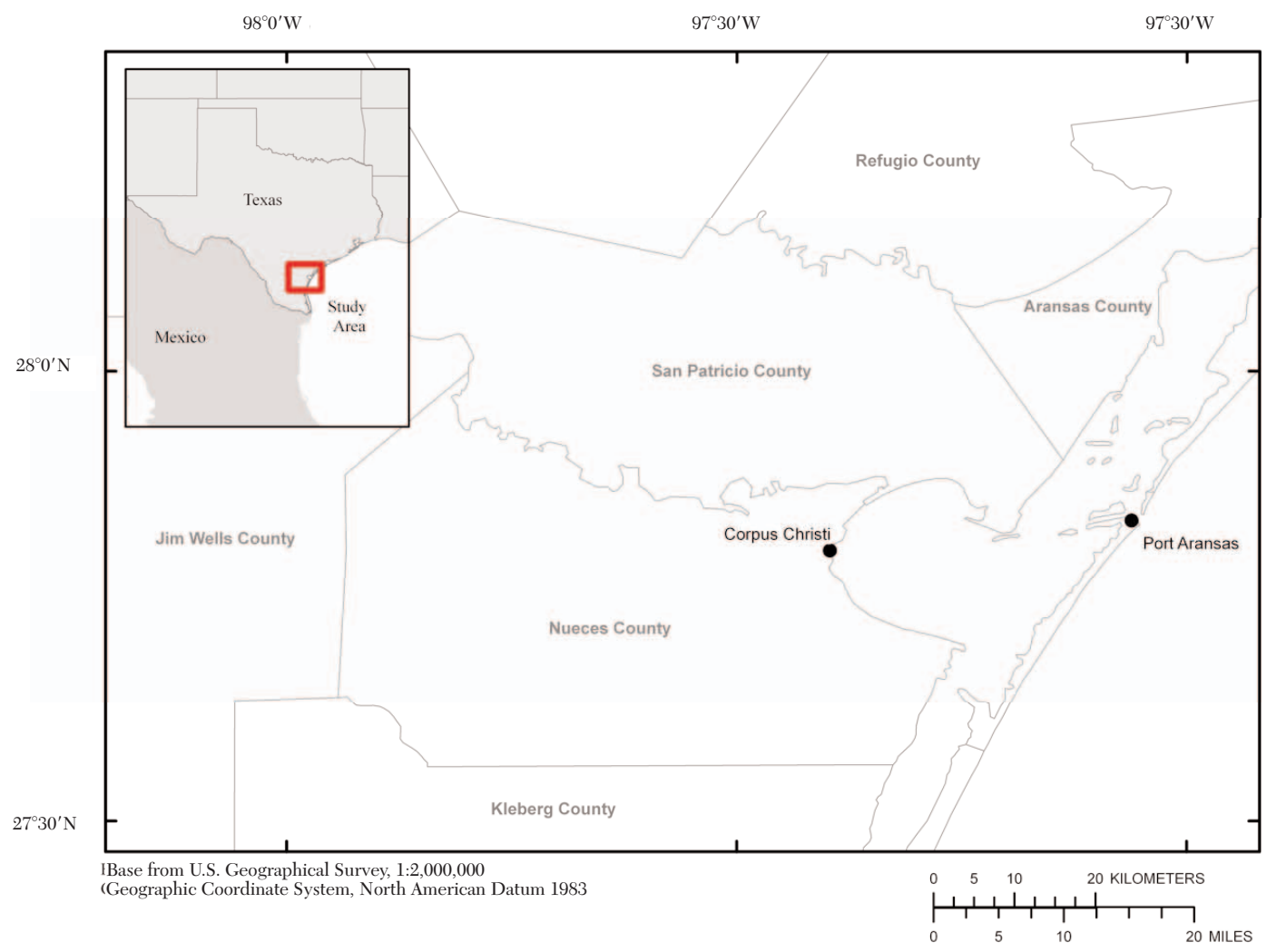

Fig. 1. Map of study area showing locations of San Patricio and Nueces counties in southern Texas.

presence and absence at roost sites of each of the 6 ground covers: bare ground, grass, forbs, crop stubble, litter, and woody vegetation. We could not analyze bare ground statistically becasuse of its high prevalence at all but a single culvert. We used a series of 2-way chi-square tests to examine associations between culvert occupancy (owl presence or absence) and presence or absence of the remaining 5 cover types.

\section{REsults}

The mean diameter of all occupied culverts $(n=34)$ was $20.9 \mathrm{~cm}\left(s_{\bar{x}}=1.5\right)$ with a range of $8-40 \mathrm{~cm}$. Unoccupied culverts $(n=100)$ had a mean diameter of $48.5 \mathrm{~cm}\left(s_{\bar{x}}=1.9\right)$ with a range of $6-100 \mathrm{~cm}$. Small culverts (diameter $\leq 16 \mathrm{~cm}$ ) were occupied by Burrowing Owls in greater proportion than were medium (17$24 \mathrm{~cm})$ and large $(\geq 25 \mathrm{~cm})$ culverts $\left(\chi^{2}=\right.$ 46.87, $\mathrm{df}=2, P<0.001)$. Likewise, a higher proportion of culverts with an east-west orientation were occupied than were culverts with other directional orientations $\left(\chi^{2}=9.15\right.$, $\mathrm{df}=3, P=0.027$ ).

Bare ground constituted most of the ground cover within a $10-\mathrm{m}$ radius of occupied culverts $(77 \%)$ and unoccupied culverts $(65 \%)$. Grass was $26 \%$ of the ground cover around unoccupied culverts and 6\% around occupied culverts. Crop stubble was $13 \%$ of the ground cover at occupied culverts and $<1 \%$ at unoccupied culverts. Forbs, litter, and woody vegetation composed $\leq 5 \%$ of the cover at both occupied and unoccupied culverts. Owl presence at culverts was associated with absence of grass $\left(\chi^{2}=26.9\right.$, df $=1, P<0.0001)$, absence of woody vegetation $\left(\chi^{2}=4.4, \mathrm{df}=1, P<0.05\right)$, and presence of crop stubble $\left(\chi^{2}=16.5, \mathrm{df}=1, P<0.0001\right)$. Culvert occupancy by owls was not associated with forbs $(P=0.10)$ or litter $(P=0.27)$.

\section{Discussion}

This study showed that Burrowing Owls wintering in southern Texas preferentially used 
culverts with diameters $\leq 16 \mathrm{~cm}$. Burrowing Owls wintering in southern Texas preferred artificial burrows with $15-\mathrm{cm}$ diameter openings (Ortega 2003, Keppers et al. 2008). Selection by Burrowing Owls of culverts and artificial burrows with small diameters is probably a defense mechanism against large mammalian predators (Clayton and Schmutz 1999).

Although substantial data exist on Burrowing Owl nest site characteristics, only a few studies have investigated factors influencing nest site selection by comparison of occupied and unoccupied nest sites. Coulombe (1971) stated that the usual burrow entrance in the Imperial Valley, California, was $20 \mathrm{~cm}$ in diameter, which is similar to the mean diameter $(20.9 \mathrm{~cm})$ of occupied culverts in this study. Other studies have suggested that Burrowing Owls select nest sites with diameters similar to those in the small size class $(\leq 16 \mathrm{~cm})$ of this study. Smith and Belthoff (2001) found that Burrowing Owls in Idaho selected artificial burrows with mean diameters of $10 \mathrm{~cm}$ more often than those with entrance diameters of 15 $\mathrm{cm}$. Poulin et al. (2005) found that Burrowing Owls in Saskatchewan selected nest burrows with an entrance height of 15-16 cm, whereas Butts and Lewis (1982) reported that Burrowing Owls in Oklahoma selected burrows with entrances of 11-13 cm, and MacCracken et al. (1985) found that nest burrows in South Dakota had a mean diameter of $13 \mathrm{~cm}$.

Winds in coastal southern Texas normally are from the southeast, except during the passage of cold fronts, which are northerly. In southern Texas, the greater occupancy of culverts oriented mostly east-west could be related to wind-tunnel effects created by north-facing culvert openings during the passage of winter cold fronts or from strong southeasterly coastal winds at other times. In contrast, orientation did not seem important in Burrowing Owls' selection of nest burrows (Rich 1986, Estabrook 1999, Belthoff and King 2002).

The major differences in the ground cover at used and unused culverts were the presence of grass and woody vegetation around unused culverts and the presence of crop stubble around occupied culverts. Most occupied culverts were located near or in farm fields where there were few nearby trees and shrubs; these roost sites were surrounded by mowed field margins and large expanses of plowed soil, which allowed the owls a clear view of approaching predators. In contrast, unmowed roadsides supported vegetation nearly $1 \mathrm{~m}$ tall during the winter, and culverts in those areas were less likely to attract Burrrowing Owls.

The association of Burrowing Owls and crop stubble suggests that this species may benefit from certain tillage practices of agriculture. Fields that retain some crop stubble offer more cover, which could better enhance the owls' cryptic coloration and predator-avoidance behavior than the sparse cover in fields that have been tilled more intensively. Other studies have found that Burrowing Owls use habitats and nest sites surrounded by low or sparse vegetation with few shrubs (MacCracken et al. 1985, Green and Anthony 1989, Estabrook 1999, Belthoff and King 2002, Machicote et al. 2004, Lantz 2005). Although Burrowing Owls are known to forage near nest sites on breeding grounds (Green and Anthony 1989, 1997), we have no evidence that foraging occurs in the vicinity of winter roost sites.

Wintering Burrowing Owls in southern Texas have been observed using roost sites near highways and urban areas and appear to be tolerant of activites such as mowing and plowing (Williford et al. 2007). Burrowing Owls also hunt along roads at night (Brenckle 1936, Ratcliff 1986). The owls' use of road culverts as roost sites and roadsides as hunting areas increases the likelihood of owl-automobile collisions (Konrad and Gilmer 1984, Haug and Oliphant 1987, Clayton and Schmutz 1999, Millsap 2002). The danger of vehicular collision is probably lower on private roads, which are not subject to heavy traffic. Additionally, owls that use road culverts may experience greater risk of predation from large raptors that also forage along roadsides (Glazener 1963, Ramsden 2003)

However, there may be an advantage to Burrowing Owls that use culverts instead of mammal burrows as winter roost sites. Although fleas are common in the mild winter climate of southern Texas, Skoruppa et al. (2006) found no fleas and only 8 lice (total) on 15 wintering Burrowing Owls examined. Of these 15 owls, $13(87 \%)$ were roosting in culverts, and none were using natural burrows (Skoruppa et al. 2006). The low incidence of ectoparasites on Burrowing Owls wintering in southern Texas suggests that the use of road culverts instead of mammal burrows for roost sites may be 
advantageous in avoiding ectoparasites, especially fleas.

Because much of the Burrowing Owl habitat in southern Texas is located on private land, more attention must be focused on gaining the cooperation of landowners. Previous research has shown that Burrowing Owls will use artificial burrows as winter roost sites (Williford et al. 2007, Keppers et al. 2008). If land management practices are compatible, landowners and managers of public lands should be encouraged to install artificial burrows in suitable habitat (i.e., open areas with short grass or sparse vegetation). Installation of artifical burrows on these lands may offer Burrowing Owls more secure (Catlin and Rosenberg 2006) roost sites, thereby reducing mortality from vehicle collisions.

\section{ACKNOWLEDGMENTS}

We thank J. Keppers, C. Littles, and A. Floyd for their assistance in the field. Figure 1 was provided by K. Chojnacki of the U.S. Geological Survey, Columbia Environmental Research Center. Our special thanks go to G.C. Hickman, G. Holroyd, H. Trefry, T. Langschied and the King Ranch, and to various landowners in southern Texas for allowing access to their land. We are grateful to $\mathrm{B}$. Ortego, B. Millsap, and 2 anonymous reviewers for providing helpful reviews of the manuscript.

\section{Literature Cited}

Аввотт, C.G. 1930. Urban Burrowing Owls. Auk 47:564565.

BElthOFF, J.R., AND R.A. KING. 2002. Nest-site characteristics of Burrowing Owls (Athene cunicularia) in the Snake River Birds of Prey National Conservation Area, Idaho, and applications of artificial burrow installation. Western North American Naturalist 62:112-119.

BlaIR, W.F. 1950. The biotic provinces of Texas. Texas Journal of Science 2:93-117.

Brenckle, J.F. 1936. The migration of the Western Burrowing Owl. Bird-banding 7:66-68.

ButTs, K.O. 1973. Life history and habitat requirements of Burrowing Owls in western Oklahoma. Master's thesis, Oklahoma State University, Stillwater.

Butts, K.O., AND J.C. LEwIS. 1982. The importance of prairie dog towns to Burrowing Owls in Oklahoma. Proceedings of the Oklahoma Academy of Science 62:46-52

Catlin, D.H., And D.K. Rosenberg. 2006. Nest destruction associated with mortality and dispersal of Burrowing Owls in the Imperial Valley, California. Southwestern Naturalist 51:406-409.
Clayton, K.M., And J.K. Schmutz. 1999. Is the decline of the Burrowing Owl Speotyto cunicularia in prairie Canada linked to changes in Great Plains ecosystems? Bird Conservation International 9:163-185.

Conway, C.J., And J.C. Simon. 2003. Comparison of detection probability associated with Burrowing Owl survey methods. Journal of Wildlife Management 67: $501-511$.

Coulombe, H.N. 1971. Behavior and population ecology of the Burrowing Owl, Speotyto cunicularia, in the Imperial Valley of California. Condor 73:162-176.

Desmond, M.J., J.A. Savidge, And K.M. Eskridge. 2000. Correlations between Burrowing Owl and black-tailed prairie dog declines: a 7-year analysis. Journal of Wildlife Management 64:1067-1075.

Estabrook, T.S. 1999. Burrow selection by Burrowing Owls in an urban environment. Master's thesis, University of Arizona, Tucson.

Glazener, W.C. 1963. Note on the feeding habits of the Caracara in south Texas. Condor 66:162.

Gleason, R.S., AND D.R. Johnson. 1985. Factors influencing nesting success of Burrowing Owls in southeastern Idaho. Great Basin Naturalist 45:81-84.

Green, G.A., AND R.G. Anthony. 1989. Nesting success and habitat relationships of Burrowing Owls in the Columbia Basin, Oregon. Condor 91:347-354.

1997. Ecological considerations for management of breeding Burrowing Owls in the Columbia Basin. Pages 117-121 in J.L. Lincer and K. Steenhof, editors, The Burrowing Owl, its biology and management including the proceedings of the First International Burrowing Owl Symposium. Raptor Research Foundation, Raptor Research Report No. 9.

Haug, E.A., B.A. Millsap, and M.S. Martell. 1993. Burrowing Owl (Speotyto cunicularia). No. 61 in A. Poole and F. Gill, editors, The birds of North America. Academy of Natural Sciences, Washington, DC, and American Ornithologists' Union, Philadelphia, PA.

Haug, E.A., and L.W. Oliphant. 1987. Breeding biology of Burrowing Owls in Saskatchewan. Pages 269-271 in G.L. Holroyd, P.H.R. Stepney, G.C. Trottier, W.B. McGillivray, D.M. Ealey, and K.E. Eberhart, editors, Endangered species in the Prairie Provinces. Natural History Occasional Paper No. 9. Provincial Museum of Alberta, Edmonton.

Holroyd, G.L., R. Rodrìguez-Estrella, AND S.R. ShefFIELD. 2001. Conservation of the Burrowing Owl in western North America: issues, challenges, and recommendations. Journal of Raptor Research 35:399-407.

James, P.C., and T.J. Ethier. 1989. Trends in the winter distribution and abundance of Burrowing Owls in North America. American Birds 43:1224-1225.

James, P.C., AND G.A. Fox. 1987. Effects of some insecticides on productivity of Burrowing Owls. Blue Jay 45:65-71.

Johnston, M.C. 1963. Past and present grasslands of southern Texas and northeastern Mexico. Ecology 44:456-466.

Keppers, J.L., M.K. Skoruppa, M.C. Woodin, and G.C. Hickman. 2008. Use of artificial burrows by Western Burrowing Owls and other vertebrates during winter in southern Texas. Bulletin of the Texas Ornithological Society 41:59-64.

Klute, D.S., W.H. Howe, S.R. Sheffield, L.W. Ayers, S.L. Jones, T.S. Zimmerman, M.T. Green, et aL. 
2003. Status assessment and conservation plan for the Western Burrowing Owl in the United States. BTP-R6001-2003, United States Fish and Wildlife Service, Washington, DC.

KonRAD, P.M., AND D.S. GILMER. 1984. Observation on the nesting ecology of Burrowing Owls in central North Dakota. Prairie Naturalist 16:129-130.

LANTZ, S.J. 2005. Nesting ecology and habitat selection of Western Burrowing Owls (Athene cunicularia hypugaea) in the Thunder Basin National Grassland, northern Wyoming. Master's thesis, University of Wyoming, Laramie.

MacCracken, J.G., D.W. Uresk, and R.M. Hansen. 1985. Vegetation and soils of Burrowing Owl nest sites in Conata Basin, South Dakota. Condor 87:152-154.

Machicote, M., L.C. Branch, and D. Villarreal. 2004. Burrowing Owls and burrowing mammals: are ecosystem engineers interchangeable as facilitators? Oikos 106:527-535.

MCIntyre, N.E. 2004. Historical and current status of breeding and wintering Western Burrowing Owls (Athene cunicularia hypugaea) in Texas. Journal of Raptor Research 38:91-95.

MillsaP, B.A. 2002. Survival of Florida Burrowing Owls along an urban-development gradient. Journal of Raptor Research 36:3-10.

Ortega, J.L. 2003. Artificial burrow use by Burrowing Owls (Athene cunicularia) and other vertebrates during winter in south Texas. Master's thesis, Texas A\&M University-Corpus Christi, Corpus Christi.

ORTH, P.B., AND P.L. KEnNEDY. 2001. Do land-use patterns influence nest-site selection by Burrowing Owls (Athene cunicularia hypugaea) in northeastern Colorado? Canadian Journal of Zoology 79:1038-1045.

Poulin, R.G., L.D. Todd, K.M. Dohms, R.M. Brigham, AND T.I. WeLLICOME. 2005. Factors associated with nest- and roost-burrow selection by Burrowing Owls (Athene cunicularia) on the Canadian prairies. Canadian Journal of Zoology 83:1373-1380.

Price, W.A., ANd G. GunTer. 1943. Certain recent geological and biological changes in south Texas, with consideration of probable causes. Texas Academy of Science Proceedings and Transactions 26:138-156.

RAMSDEN, D.J. 2003. Barn Owls and major roads: results and recommendations from a 15 -year research project. Barn Owl Trust, Ashburton, Devon, U.K.

Rappole, J.H., and G.W. Blacklock. 1985. Birds of the Coastal Bend: abundance and distribution. Texas A\&M University Press, College Station.

RatclifF, B.D. 1986. The Manitoba Burrowing Owl Survey, 1982-1984. Blue Jay 44:31-37.

Restani, M., L.R. Rau, and D.L. Flath. 2001. Nesting ecology of Burrowing Owls occupying black-tailed prairie dog towns in southeastern Montana. Journal of Raptor Research 35:296-303.

RicH, T. 1986. Habitat and nest-site selection by Burrowing Owls in the sagebrush steppe of Idaho. Journal of Wildlife Management 50:548-555.

Rich, T.D., C.J. Beardmore, H. Berlanga, P.J. Blancher, M.S.W. Bradstreet, G.S. Butcher, D.W. DerMarest, ET AL. 2004. Partners in Flight North American Landbird Conservation Plan. Cornell Lab of Ornithology, Ithaca, NY.

Shyry, D.T., T.I. Wellicome, J.K. SchmutZ, G.L. ErickSon, D.L. Scobie, R.F. Russell, and R.G. Martin. 2001. Burrowing Owl population-trend surveys in southern Alberta: 1991-2000. Journal of Raptor Research 35:310-315.

Skoruppa, M.K., B. Pearce, M.C. Woodin, and G.C. Hickman. 2006. Ectoparasites of Burrowing Owls (Athene cunicularia hypugaea) wintering in southern Texas. Texas Journal of Science 58:73-78.

Smeins, F.E., D.D. Diamond, and C.W. Hanselka. 1991. Coastal prairie. Pages 269-290 in R.T. Coupland, editor, Natural grasslands: introduction and western hemisphere. Ecosystems of the World 8A. Elsevier, Amsterdam.

Smith, B.W., AND J.R. Belthoff. 2001. Effects of nest dimensions on use of artificial burrow systems by Burrowing Owls. Journal of Wildlife Management 65:318-326

Trulio, L. 1997. Burrowing Owl demography and habitat use at two urban sites in Santa Clara County, California. Pages 84-89 in J.L. Lincer and K. Steenhof, editors, The Burrowing Owl, its biology and management including the proceedings of the First International Burrowing Owl Symposium. Raptor Research Foundation, Raptor Research Report No. 9.

Wellicome, T.I., and G.L. Holroyd. 2001. The Second International Burrowing Owl Symposium: background and context. Journal of Raptor Research 35:269-273.

WiLliford, D.L., M.C. Woodin, M.K. SKoruppa, AND G.C. Hickman. 2007. Characteristics of roost sites used by Burrowing Owls wintering in southern Texas. Southwestern Naturalist 52:60-66.

Woodin, M.C., M.K. Skoruppa, AND G.C. Hickman. 2007. Winter ecology of the Western Burrowing Owl (Athene cunicularia hypugaea) in southern Texas 1999-2004. United States Geological Survey Scientific Investigations Report 2007-5150.

Received 17 January 2008 Accepted 15 September 2008 